\title{
IKAP
}

JKAP (Jurnal Kebijakan dan Administrasi Publik) Vol.21 (1), May 2017, 1-12

ISSN 0852-9213 (Print), ISSN 2477-4693 (Online) Available Online at https://journal.ugm.ac.id/jkap

\section{Ecocracy : Ecology Based Democracy \\ Pursuing Local Goals of Sustainable Development in Indonesia}

\author{
Retnayu Prasetyanti \\ Public Administration Department \\ University of 17 Agustus 1945 Jakarta \\ retnayuprasetyanti@yahoo.com
}

\begin{abstract}
This paper analyses the need for ecology based democracy to achieve sustainability in local development. Research results indicate that the development of democracy as it was mandated in the Green Constitution has directed the implementation of the Local Sustainable Development Goals using Ecocracy principles. The new trend of Open Local Government and Green Economy by strengthening the strategies of gender development and Ecoregion has recognized the sovereignty of the environment in local development. A qualitative CATWOE analysis concludes that in the context of local sustainable development, the ideas of Ecofeminism and Ecoregion practically take into consideration local factors which are unique and different due to the nature of diversity. Consequently, the key principle of Ecocracy must be enhanced comprehensively through enhanced participation, transparency, law enforcement, sustainability, local wisdom (socio-culture), equality (gender), accountability, efficiency and effectiveness, and welfare.
\end{abstract}

Keywords: democracy, ecocracy, ecofeminism, ecoregion, green constitution, open local government, sustainable development 


\section{INTRODUCTION}

Democracy of development; as it was preached in green constitution apparently mandated the principles of sustainability in development. The trend of Green Economy encourages the idea of eco-philosophy based local development. Meanwhile, the highest level of democracy development today is democracy based on legal framework law (constitutional democracy) (Supardan, 2015). From this perspective, understanding the legal framework is crucially important in as much as serves as a basic guidance of the governance system. Thus, democracy without a constitution is not ideal, but defective.

In the era of modern governance, political decentralization is considered the manifestation of democratization of development. Consequently, the formal management of policy and strategies of development is vested in different regions of the autonomous provincial and district governments. However, the shifting of power requires coordination to create a balance in political power of the local development policy making process. The management of the process of local development is based on Law No. 25/2004 on National Development Planning System and Law No. 32 / 2009 on the Protection and Management of the Environment. The two laws stipulate clearly the provisions on participatory based environmental development as a reflection of Law No.23/ 2014 on Local Government. Thus, the urgency of Ecocracy is undeniable, largely due to the severe deterioration of the environment that in turn has triggered disasters and destruction. Large scale land conversion has become common place and widespread; modernization of urban area has destroyed more than $60 \%$ of green area; and by 2015 , $70 \%$ of agricultural land in rural areas had been lost to conversion for other uses.

The notions of democracy and ecology (Ecocracy) have sparked intensive discussion from many actors. Inherently, democracy respects diversity and equality in life. For more than 2 decades, development has been dominated by the discourse on ecology and democracy. Academic practitioners and policy makers have committed themselves to implementing the principle of democracy as the lynchpin of political influence on the environmental policy making process. Practically, environmental practitioners, sociologists, experts, and Green Economy activists have campaigned vigorously on the crucial impact of Open Local Government and political institutions on development.

Globally, the United Nations has established a legal framework that is underpinned by Sustainable Development Goals (SDGs) with 17 main goals of world development. Locally in Indonesia, SDGs principles and Ecocracy are considered the basis for formulating alternative policies which will underpin local development goals. The contention is presented on the basis of some actual analyses that include: (a) the development of the green constitution and Ecocracy in the era of Ecocentrism, (b) the analysis of Ecocracy from the perspective of CATWOE analysis, (c) the strategy to pursue Local Sustainable Development Goals through Ecoregion and Ecofeminism as a response to the current trend in gender development

Meanwhile, some of the theoretical framework that underpin the paper include, (a) the linkage between the theory of democracy and ecology includes the framework of Ecocracy by highlighting the urgency of the green constitution and Ecocentrism. This analysis tool regards Ecocracy as the best perspective that provides a balance of life in age of destruction and damage. From this point of view, Ecocracy complements democracy by linking it with ecology engagement. (b) the theory of deep ecology with perspectives of Anthropocentrism and Biocentrism. The theory relates to the analysis of the ongoing policy debate on how to improve local environmental policy. Ecocracy may provide brief policy alternatives of the Ecoregion and Ecofeminism movement by putting environment, people, and economy at equal footing in development.

Relevant research on Ecocracy entitled "Developing Community Based Solid Waste Management Scenario in Surabaya, East Java, Indonesia: An Analysis Using System Dynamic Method" revealed the need for local context based sustainable development. The research is strongly related to the idea 
of gender development in Ecocracy (Prasetyanti, et., al., 2014). An equally relevant reference is "Ekofeminisme: Peran Perempuan dalam Lingkungan" which discusses the empowerment of women in local development (Astuti, 2012). The key finding is that for sustainable ecocracy to succeed, women must be empowered to become agents of the environment and community empowerment.

The study uses qualitative research methodology, which is underpinned by a descriptive analysis. The approach describes and defines the complex transformation process of Ecocracy in pursuing local sustainable goals in Indonesia (CATWOE analysis as part of a systematic analysis drawn from Soft System Methodology). Presentation of research results is purposely made in such a manner that they can enrich public administration discourse by combining the analysis of democracy and sustainable development.

The terminology Ecocracy in public administration is quite new. It embodies green philosophy and tries to reevaluate the green constitution within the framework of local development. In short, the analysis in this paper attempts to argue and advocate for Ecocracy in the implementation of local sustainable development goals. The writer intends to lend support for taking into account and involvement of social capital in local development through Ecoregion and Ecofeminism analysis. Moreover, Ecocracy is projected as some realistic utopia; a philosophy to redefine what is good in the governance era. The need to create fundamental and monumental role of Ecocracy in maintaining the linkage, interaction and dynamic utilization of natural resources and the process of democratization, is also another core motivation for this study.

\section{The Urgency of Democracy and Ecology}

The principle of democracy has a close relationship with nature. Pluralism is natural, nature is diverse, and diversity is democracy. Democracy, or the level of its development, determines the impact that political ethics have on environmental preservation. It can generally determine the way political actors shape and influence the sustainability of the democratic process. In other words, sustaina- bility of democracy is affected by morality, which is in decline today. There strong fear that the existence of low democratic governance will arouse strong public reaction. Politically unstable situations, are expected to endanger efforts at strengthening legal environmental protection (green constitution). Strong and deeper democracy, from the sustainable development perspective, has several moral multi perspective principles, interalia:

Firstly, democracy guarantees and respects pluralism; tolerates diversity of political aspirations and values from both individuals and political parties. Current public opinion tries to equate environmental values to political and economic agendas. Sustainable development paradigm must be understood as a plural dimension. In other words, perceiving the concept of development as limited to economic development, and confining democracy to political aspiration, pose the danger of putting attention to the environment last.

Secondly, democracy guarantees and respects freedom. Democracy accepts the demand and aspiration to pursue and promote public welfare. Principally, the quality of life reflects the quality of human development index and environmental quality index, which are indirectly tailored toward fostering sustainability. Democracy connects people to the government; it connects the poor to the philanthropists; it also transmutes differences into of commonality. It respects every person, every culture, and every element of development (economic, social and environment) under the integrated political system of democracy.

Thirdly, democracy guarantees human rights and nature rights. Policy stakeholders must sustain and protect the rights of nature, as well as the rights of human beings. In today's modern world, democracy rejects the supremacy of human rights beyond above nature rights. Humans cannot be accorded legal rights to take blatantly destructive actions against the environment without any responsibilities to guarantee its sustainability. The United Nations Conference on Environment and Development in June 1992 established a set of common goals to preserve global environment against global warming. 
While the study of democracy and ecology is not new, Ecocracy analysis is quite rate. Basically, there is a close and integral link between democracy and human development. It is evident that democratic people are an embodiment of the great achievement of the human development process. Transparency and participation are important components of democracy principles; meanwhile a transparent and an active society indicates a successful human development process.

The recent political state of political democratization has fostered human development and enlightened, and deepened the spirit of sustainability in the governance era. The performance of Indonesia on United Nations Development Program (UNDP) Human Development Index (HDI), shows Indonesia being ranked 110th out of 187 countries, with an index value of 0.684 . From simple calculation, it is evident that from 1980 to 2015, Indonesia's HDI has registered a $44.3 \%$ increase. Nonetheless, public criticism on underperformance of Indonesia on HDI has been leveled at the failure of Indonesian society to pay serious attention to environmental preservation issues. Indeed, as clearly stated in the Human Development Index (2015), which was published by the United Nation Development Program (UNDP), HDI measures three main aspects of, which include: (a) a long and healthy life, (b) knowledge, (c) a decent standard of living. A long and healthy life reflects the degree of life expectancy index. Indonesia registers life expectancy index of 70.1 years, which is 0.4 points higher than 70.5 years for Bangladesh. In Asia, Indonesia only outperformed India, Philippines, Kazakhstan, and Myanmar, whereas Malaysia registered life expectancy of 74, 9 years. The poor performance of Indonesia on life expectancy component of HDI relates to the country's under performance on the decent standard of living variable, which reflects a balance between economic and a healthy environment. Accordingly, there is need for the central government and local governments to take serious measures and efforts that promote the creation of sustainable nation in future.

\section{Enabling Green Constitution and Ecocra- $c y$ in the Framework of Ecocentrism: Crit- ics of "Green" Terminology}

The terminology "green" is fancy/ trendy today. Nonetheless, the reality is that its use reflects more illusory than facts on the round prove. "Green" seems to be recognized as Eco-myopia", a false common understanding of the environment. In reality, "Green" must be understood as the path of development, a framework of thinking, direction of design, and pattern of life.

The creation of an effective environmental management process is underpinned by a constitution that respects and upholds diversity, which may vary from one country to another in line with differences in various contexts. For example, Portugal and France are two countries, which have established a green constitution for the sustainable environment and people as an integral part of human rights. Portugal's constitution in 1976 stipulated that it is the duty of the state to protect the environment and rights of citizens. Meanwhile, France is a little behind compared to Portugal, in that regard. However, France, in the process of the constitutional amendment in 2006, the state showed strong will and commitment to put the environment in the preamble of the constitution. Ecuador is the most superior in incorporating the environment into the constitution. In the new constitution that was promulgated on 10th April, 2008, the rights of environment have are aligned with human rights. Thus, conceptually, the environment is no longer regarded as a complementary to human rights.

The Indonesian constitution (UndangUndang Dasar 1945) after the amendment in 2002, incorporates movements towards becoming green. The spirit of the green constitution is stipulated in Article $28 \mathrm{H}$ clause (1) and Article 33 clause (4) of the Constitution. Article 28H Clause (1) states that "Every citizen has the right to achieve social welfare in both physiologically and spiritually, have decent place to stay, have access to a good and healthy environment, and right to health care”. Whereas, Article 33 Clause (4) states that the national economy shall be administered in the form of an economic democracy that is underpinned by principles of togetherness, efficiency of Justice, environmental 
Table 1. Resume of CATWOE Analysis on Ecocracy (Data Analysis)

\begin{tabular}{|c|c|c|}
\hline Component & Information & $\begin{array}{c}\text { Stakeholder Identification } \\
\text { on Ecocracy }\end{array}$ \\
\hline $\mathrm{C}=$ Customer & $\begin{array}{l}\text { - People who feel the out- } \\
\text { put/outcome/impact of A } \\
\text { (Actors) } \\
\text { - People who might be af- } \\
\text { fected by a problem and } \\
\text { how do they solve it? }\end{array}$ & $\begin{array}{l}\text { a. Non-Governmental Or- } \\
\text { ganization } \\
\text { b. Private sector } \\
\text { c. Civil society } \\
\text { - Structurally Weak Cate- } \\
\text { gory (CLASS: The poor, } \\
\text { unemployment, and low } \\
\text { cost labor; GENDER: } \\
\text { Female; RACE/ETNIC: } \\
\text { Local community and } \\
\text { minority group. } \\
\text { - Special Weak Category } \\
\text { (Old people, children } \\
\text { and teenager, physic and } \\
\text { mental defect, gay and } \\
\text { lesbian, isolated people } \\
\text { (geographically or so- } \\
\text { cially)) } \\
\text { - Personally Weak Cate- } \\
\text { gory (Troubled people in } \\
\text { individual, family, grief, } \\
\text { and loss) }\end{array}$ \\
\hline
\end{tabular}

Analysis: Customer in Ecocracy refers to secondary actors, hence excludes governmental bodies. This means that supporting actors in the governance process need to be served and informed, and private customers generally obtain best services from company. In Ecocracy, customers are not specifically divided into certain groups, but general entities that effect change in environmental preservation. Mainstream society has the same responsibility as eco-community lovers such as NGOs, or the private sector that conducts activities that are motivated and underpinned by environmental preservation goals

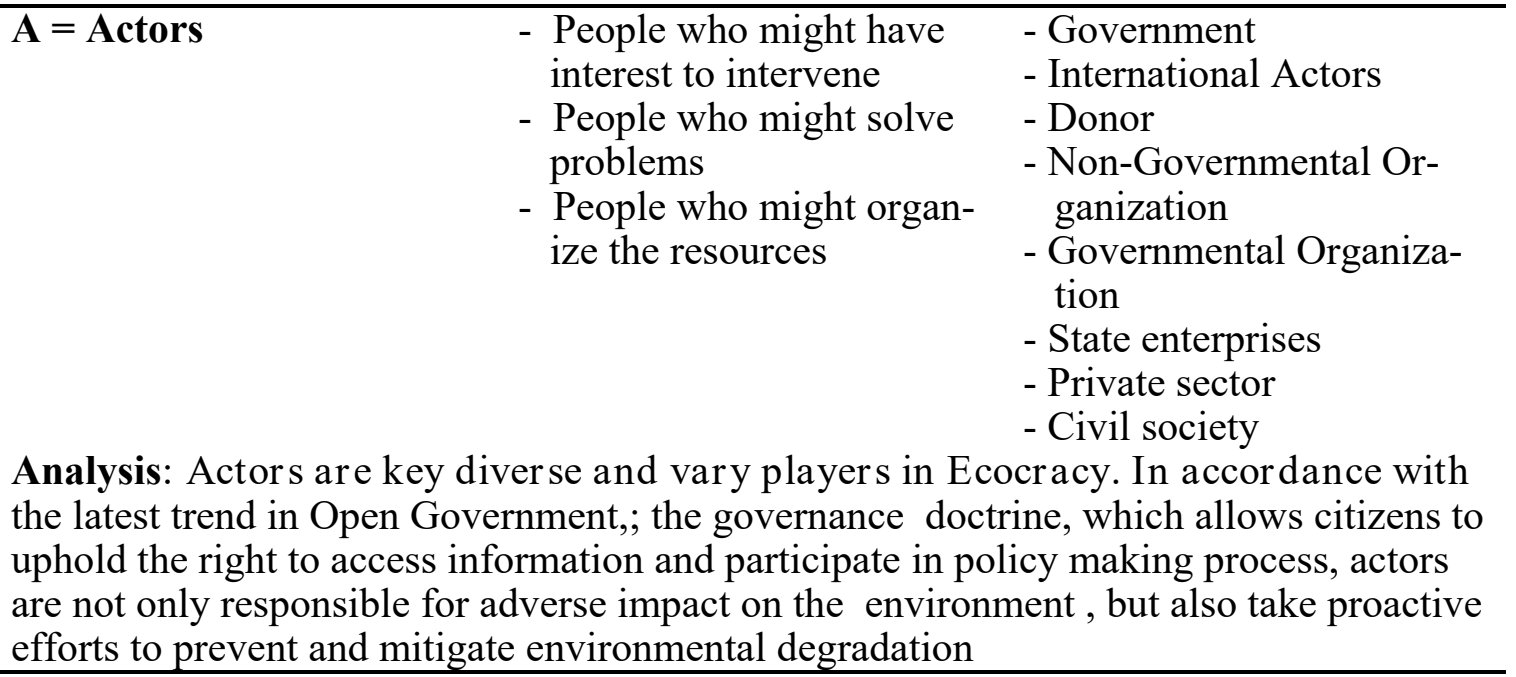




\begin{tabular}{lll}
\hline T $=$ Transformation & - Process of change & - Government \\
& - Input- output variables & - International Actors \\
& and indicators & - Donor \\
& - Non-Governmental Or- \\
& ganization \\
& - Governmental Organiza- \\
& tion \\
& - State enterprises \\
& - Private sector through \\
& - Civil society \\
\hline
\end{tabular}

Analysis: A process comes from inputs (demand, issues, problems and necessity). Ecocracy facilitates aspiration and demand of eco-saving and go green campaigns to the an ecology-based policy formulation political process, and delivers it as the output to the public as regulations, norms, and rules. Further analysis of Transformation is explained in the Input-Output Diagram (see table 2).

\begin{tabular}{lll}
\hline $\mathbf{W}=$ Worldview & - Individual belief & - International politic \\
& - State's ideology & - Culture \\
Perspectives & - Global economy \\
& - Social \\
& - Environment \\
\hline
\end{tabular}

Analysis: the stability of global politic and economy is substantial. Globalization influences governance, policies, and national economic growth. In sustaining a nation, which is vital for balanced development, fair democracy, and/or Ecocracy must be enhanced. Global actors may influence national development policies, which is why law enforcement should not be under the control of international forces, including capitalists. Sustainable ecocracy requires maintenance of welfare through the preservation of nature and local resources.

\begin{tabular}{lll}
\hline O= Owners & - People who might hold & - Government \\
& power & - International Actors \\
& - People who might con- & - Donor \\
& trol policies & \\
& &
\end{tabular}

Analysis: In the modern governance system, the central government not longer plays the role of being the best single actor in state. However, when international influence and power increases leads to greater international intervention into environmental policies. In this case, donors no longer play the role of fund raisers, but also key players in planning, program implementation, monitoring and evaluation, including making public reports. Furthermore, the problem lies in orientating those actors to ensure that they focus on their goals as well as arranging the mechanisms that helps to realize those goals.

\begin{tabular}{lll}
\hline E = Environment & - Elements outside the sys- & - Politics \\
tem (driving and con- & - Law \\
straining factors) & - Culture \\
& - Economic \\
& - Social \\
& - Environment \\
\hline
\end{tabular}


Analysis: Ecocracy environment is diverse; in the per spective of CATWOE analysis, the environment is the determining factor that influences supporting and inhibiting factors. These factors are many; however conducting a field analysis of influencing forces leads to the conclusion that politics and law are the most significant factors that important in upholding Ecocracy. While green politics can ensure that environmental policies are promulgated fairly, law enforcement is expected to ensure that equality is observed through monitoring policy implementation. In social forces from community and the commitment of business sector in Green Economy are major to succeed Ecocracy.

sustainability, environment based knowledge, independence, and through maintaining the balance between the economic advancement and unity of national economy.

An appraisal of the Indonesian constitution, which was undertaken by Sonny Keraf (a famous academic practitioner on environment related issues), notes that Indonesia's constitution has oriented towards becoming a green constitution. On the contrary, the reaction of Emil Salim (a former Minister of Environment) was criticism of the constitution of Indonesia for lacking a more aligned vision with the law. Emil argued that the constitution of Indonesia is very much in line with law enforcement process, which makes it strong on emphasizing law and politics as they relate to economic development but weak on environmental preservation.

Green constitution must highlight environmentalism, which ensures sustainability in positive laws. Consequently, the central government and local governments must ensure sovereignty and sustainability of the environment. This is the mindset that underpins the green philosophy and is inspired by the existence of numerous events of environmental deterioration and degradation such as natural disasters, deforestation, and famine. The adherents of environmentalism and later known as Ecocentrism rejects the values of antropocentrism, which is the mainstream hence underpins the thinking and practices of society today.

The emergence of environmental regimes such as the Kyoto Protocol and the United Nation Convention on Climate Change (UNFCCC) has proven that current public awareness about the importance of global environmental sustainability is in- creasing. No matter how much natural wealth a country may have, no matter how great the political power and sophisticated technology a country develops, the future of the environment will be in jeopardy unless good democracy takes hold.

The existence of a green constitution supports the sovereignty of the environment as an Ecocracy; and fosters the preservation and sustainability of rights of the environment. The idea behind the above concepts are inspired by perspectives of theocracy (the sovereignty of God), democracy (the sovereignty of people), monocracy (the sovereignty of law), and monarchy (the sovereignty of king). Ecocracy tends to focus on paying a lot of attention to the ecology as the core component of governance system. Nonetheless, the perspectives of Ecocentrism, environment and people are connected between one and the other; there are ethics and rules in the theory of Deep Ecology. Deep Ecology, was first expounded by Arne Naess in 1973 in a book entitled "The Shallow and The Deep, Long-range Ecological Movement: A Summary". The theory created a new ethic of a comprehensive system against Antropocentrism and Biocentrism, which are only concerned with the existence of human beings and other living creatures. The new ethic prioritizes morality and caring, while also preserving sustainability and socializes the crucial importance of an ecology community as a holistic element of an ecosystem.

In the Ecocentrism framework, a practical ethic attempts to create concrete action against environmental deterioration. Based on knowledge of Ecocracy, the demand for strong state institutions is necessary to achieve balance in the environmental, social and economic conditions. The benefits of 
Ecocentrism era vary and include; firstly, it creates potential for identifying models such as social or liberal democracy, and definitely Pancasila democracy. In early 1983, Indonesia accomplished the achievement of winning the top prize in Asia's agricultural sector. At the time all development agendas were centralized and politicalized, the central government was the only one that had control over the design, formulation of policies that were implemented by local governments through national development guidance known as Garis-garis Besar Haluan Negara (GBHN).

On the contrary, the regime of democracy today; which is expected to be more specific as an Ecocracy, has the goals of promoting not only political and economic advancement, but also sustainable development in the management of a diversity of natural and cultural resources. Secondly, Ecocentrism creates opportunities for improving governance, at both the central and local government levels. In that regard, the emergency of public engagement within the framework of Open Government (national platform of state management system) is considered to be one of the most remarkable developments in the history of secretive /closed governance system. Moreover, the success of open Government and Ecocracy are expected to lead way for the emergence Open Local Governments and the permeation of Good Corporate Governance in local government institutions.

\section{RESULTS AND DISCUSSION}

\section{Systemic Analysis (CATWOE Analysis on Ecocracy}

CATWOE analysis is part of thinking framework which is commonly included into soft system methodology. In this paper, CATWOE analysis is used to identify stakeholders and analyze the system of Ecocracy with considerations of critics, possibilities and challenges both in theoretical and empirical perspectives (Table 1). CATWOE analysis was previously used as a tool of analysis in business sector. It is capable to explain business's forecast and measure the best profit estimation. In the system of Ecocracy, CATWOE analysis is used to identify policy stakeholder and summarize the role of each actor.

\section{Ecofeminism in Local sustainable develop- ment}

Vandhana Shiva (a prominent Ecofeminism) has campaigned widely for Ecofeminism in the world figure. Vandhana Shiva, in her contention on ecofeminism supports the sustenance perspective, hence criticizes vehemently Develop mentalism idea. She has been responsible for spreading the critical perspective of modern imperialism as manifested in Developmentalism practices. In addition, Shiva considers international developmental assistance or grants as inimical to the spirit of independence in managing local development in Third World countries. Developmentalism like feminism movement was designed under the same paradigm; a patriarchy, a masculinized system (Fadlurrahman, Lalu. 2014:162). This criticism refers to universal concepts of development, which do not take into account the originality of local wisdom and indigenousness (Mies \& Shiva, 2014).

The Green Revolution was yet another global slogan of the go-green movement. Nonetheless, the concept also faced criticism for being a westernized environmental development concept which compelled uniformity in environmental development without respecting local values. Most critics of the Green Revolution are based on the global mindset it perceives it perceives of traditionalism which it considers primitive and inferior. For some reasons, the Green Revolution and Developmentalism are basically more economically oriented than environmental. The above global mandates did not only support economic environmentalism, but also supported the dominating influence in re-shaping a universal guideline of international development, which in general induced and perpetuated international dependency (Mies and Shiva, 2014).

Recently, Ecofeminism has come to be regarded as one of the most appropriate strategies of development in Indonesia. This is because, ecofeminism is an apt response to the recognition of community empowerment and social capital in local development. Besides, the potential threat from global 
Table 2. The Input Output Diagram (Data Analysis)

\begin{tabular}{|l|}
\hline \multicolumn{1}{|c|}{ Uncontrolled Inputs } \\
- Capitalist economy system \\
- Land conversion \\
- Rapid population and urbanization \\
- Mass Consumption \\
- Inconsistency of regulations \\
\hline
\end{tabular}

\begin{tabular}{|l|}
\hline \multicolumn{1}{|c|}{ Expected Outcomes } \\
- Green Economy \\
- Open Local Government \\
- Good Corporate Governance \\
- Community Empowerment \\
\hline
\end{tabular}

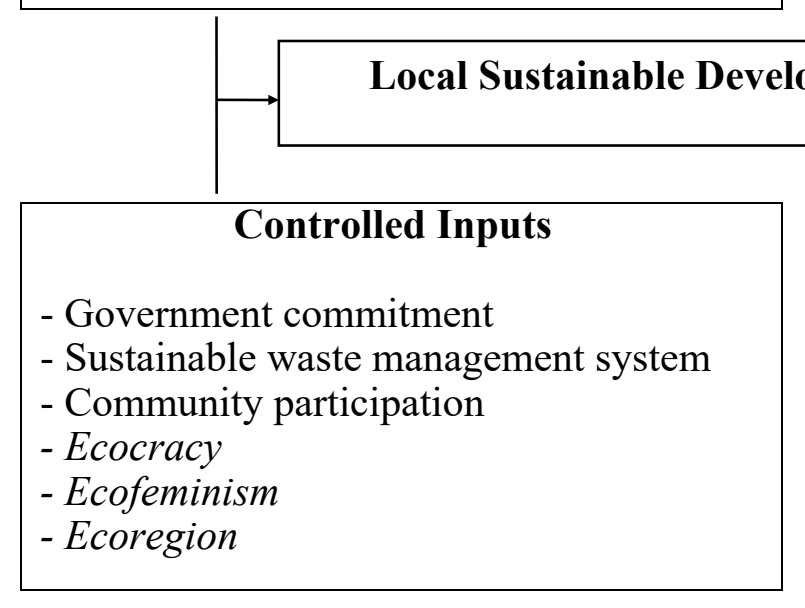

warming that is attributable to disequilibrium in human interaction with the environment has smoldered the spirit of feminist movement to impede earth destruction (Shiva, 2015).

The ecofeminism movement, or the ideology of the ecology of feminism stems from an assumption that the exploitation and expansive hegemony is likened to the women's role. Women have experienced and got involved in social, economic, cultural, and political movements that put them into positions of main actors. One of the unique facts about Ecofeminism is the assumption that there is a close relationship between the oppression that affects women and the repression that is meted out to nature. From the vantage point of ecology, thus, Ecofeminism is often regarded as a theory and movement that attempts to stifle the existence of. This is because Anthropocentrism puts humans in the highest position with respect to making decisions of morality and ethical considerations in development.

HDI (woman) in Indonesia shows an upward trend over time. However it is not difficult to see that HDI for men is significantly higher than that of women, (table 2).
To that end, HDI developments can portray the achievement that Ecofeminism movement has made, and what needs to be done in future.

Support for Ecofeminism is an appreciation of the essential role of women family and social life. It is also a response to the disproportionate distribution of benefits of development which the poor perceives about development, including women (Prasetyanti, 2015). Socially, women play such important roles as decision makers, facilitators and leaders in environmental movements that are tailored toward promoting the Ecofeminism perspective. Hyogo Framework of Action (HFA), which was an outcome of the World Conference on Disaster Risk Reduction that was held by The United Nation in 2005, was one of the venues where recognition of the importance of gender perspective took center stage. HFA emphasized the importance of civil engagement, including women, in disaster risk management and decision making processes, education and training.

Nonetheless, while Ecofeminism has its strengths, it is not devoid of weaknesses. 
Some critics point to the nature of women lately. There is common understanding that rural women tend to have strong social bonding and friendship if they hail from the same social and economic status/level. Urban women on the other hand, trend to be more consumptive which inhibits their ability to manage social life. Such behavior, in turn influence their social bonding in community that subsequently culminates in difficulties urban women face in achieving Ecofeminism goals. Other problems are relate to the economic gap that separates between rich and poor women poor women. This classic problem may become even more serious for women who have low empathy. On the contrary, urban women who the high educational attainment and knowledge do not encounter such difficulties. For example, the practice of Ecofeminism in in Surabaya (Women based Solid Waste Management program - development program funded by the USAID that got underway in 2006 in six Hamlet, in Wonokromo Urban Village, has underscored and highlighted major roles that women can play in a sustainable development program. In the above program, women have succeeded in facilitating training and education (mezzo strategy) on proper solid waste management in urban areas (Prasetyanti, et., al., 2014).

On the global context of sustainable development agenda, gender equality is listed in point 5 , while on the national context, regulation of gender equality and environmental policy falls under Law No. $32 / 2009$ on the Environmental Protection and Management. Various roles of women in Ecofeminism include: (a) environmental cadres, (b) coordinators in economy-based environmental program, such as recycling (Bank Sampah), (c) representatives in environmental policy making process, (d) leaders and facilitators in community empowerment, (e) conflict mediators to maintain diversity and tolerance.

\section{Ecoregion based Local Sustainable Devel- opment}

Overpopulation and urbanization have contributed to making local development into an extremely complicated process. An overpopulated area, leads to congested utilities and services due to demand exceeding capacity. For instance, roads no longer satisfy the needs of a growing population, while farmlands and forests are sacrificed to build malls and housing developments (Kalu and Okhorafor, et. al. 2014). Yet, local economic transformation faces serious problems; interalia lack of capital, skills and entrepreneurship to process development. This indicates the need for local context to have a certain strategy it is to achieve sustainable development (Nugroho, Iwan, etal. 2016). Moreover, the capability of every region to develop their respective regions varies due to differences in available natural, human, artificial resources and social resources potential (Nurpita, Anisa and Aulia A. N., 2016).

Ecoregion is defined as a certain geographic area that has common characteristics such as climate, soil, water, flora, and fauna, as well as patterns of human interaction with nature that describes the integrity of natural systems. Economic activities that rely on natural resources should be based on Ecoregion where the management of the exploration activities of all natural resource must be preceded by an Environmental analysis exercise (AMDAL). Ecoregion lays more emphasis on the importance of the existence of green space area in local spheres of development (Setyati, Rina and Warsito Utomo, 2015). In the Ecoregion perspective, the local planning and development process must take into account the diversity of the ecosystem, population density, natural resource distribution, local wisdom, and climate change.

Moreover, ecoregion plays an important role in supporting the Green Economy in local development. Green Economy is part of the socioeconomic activities that rely on natural resources without causing deterioration to natural resources. The economic activities can be in the field of mining, use of forests that is done in accordance with local unique features. Moreover, Law No. 32/2009 mandates the spirit of Ecocracy to strengthen national and local development planning/strategy by maximizing governmental coordination and public participation. Principally, Ecoregion guarantees good and healthy environment, as well as providing protection to the entire ecosystem in pursuing local sustainable development.

The urgency of Ecoregion in sustaining 
local development must be consummated through the establishment of clear classification of land use and natural resources. Generally, Ecoregion principles can be applied in land use planning system, such as farming system. That way that works is through classification of each region in every province have superior product for development, and the obligation to explore and exploit resources, while preserving the environment. Land conversion is regulated in law. Land conversation can be into farming areas/ agriculture or forest areas. Some cases of land conversion are harmful.

Nonetheless, in practice, the use of land for agricultural purposes in such a manner that does not flout environmental preservation is very much line with Ecoregion principles. Contrariwise, conversion of land use accompanied by disregard for environmental preservation has adverse impact on land.

In 2006, land use conversion in the agriculture sector in Sukolilo Pati, Central Java became a national issue due to the emergence of documentary movie entitled "Samin vs Semen": a public criticism about the construction of the Cement Company (PT. Semen Gresik). The conflict has been phenomenal. The company (PT. Semen Gresik) has converted agricultural land into an industrial area that stretches for more than 2000 hectares. This case is very much in contrast to principles of a Green Economy and Ecoregion, which underscore the importance of, and are underpinned by, appropriate land use through taking into consideration requisite sustainability management.

At the national level, the government has created a legal framework for forest conversion, and laid out what activities constitute criminal acts such as deforestation and illegal logging. The provision on criminal activities is enshrined in Article 50, while sanctions are laid out in Article 78, Law No. 41/ 1999 on Forestry. The sanctions, emphasize the need to ensure forestry management and sustainability. Nonetheless, the weakness lies in the poor enforcement of law provisions. The conversion of forests into oil palm plantations poses major threat to the sustainability and conservation of forestry and animals; and has caused heavy flooding and landslides in certain local areas. Moreo- ver, continuation of such activities poses the danger to create irreversible damage to biophysical conditions such as climate change, ecosystems, and disruption of water management in future. Inevitably, unless such threatened are averted, they will unleash adverse social impact to current and future generations.

Local governments play a very big and substantial role in the Ecoregion is indeed substantial. Firstly, local government represents the existence of institutional sustainability. This is because governmental institutions determine the rules of the game on which local sustainable development is built, shaped, and directed. Secondly, the local government conducts the distribution of and influence power to manage policies (Rijal and Syaifullah, 2013). In the local autonomy era, local governments are authorized to manage and administer the use and distribution of agriculture and forestry resources, including eland conversion. Moreover, land conversion must be controlled by the local authority and public participation through law enforcement and Ecocracy. This may ensure certainty of community empowerment in supporting Ecoregion policy, which relies on the uniqueness of physical character and social capital of the local area (Widayani, Retno and Nisa A. R, 2013). Ecoregion concept is also relevant with respect to the policy of conversion of land for housing area. This is through the establishment of certain portions of land conversion specifically for designated green area or housing area. For example, in rural areas, good village governance is expected to underpin and reflect the success of development at the national level; this is a NAWACITA's program called Program Membangun Desa. Thus, the above program is one of the manifestations of good village governance that focuses on village management strategy to achieve local sustainable development goals.

\section{CONCLUSION}

Ecocracy is enshrined in the Green constitution. Economic democracy in the realm of development while often assumes center stage in development discourse, does not make the importance of democracy in 
ecology in development any less vital. In the context of local development, Ecocracy must be developed locally based on certain characteristics that are unique. Thus, the policy package for each area must be different, and must encompass all that is required at the village, neighborhood, sub district, and district levels.

Good village governance, which is needed to ensure that Ecofeminism and Ecoregion, can only succeed if community empowerment is enhanced and sustained. From the governance perspective, each supporting party has the power to influence policy by contributing their aspirations into inputs and interests. Therefore, the realization of Open Local Government and Good Corporate Governance is needed if a balance in the contribution of the public and private sector in local development.

Research recommendation emphasize the need for institutional sustainability to underpin local sustainable development in Indonesia (the need for the creation of sustainable institutions for example). Like other development strategies, local sustainable development must rely on three major considerations including (a) geographical consideration (climate, spatial border, agriculture and maritime, land typology and topography, natural resources, climate); (b) demographic consideration (social capital, culture, local wisdom, HDI, ecofeminism); (c) Environmental consideration (disaster and risk management, environmental vulnerability, such as slum and waste, forest fire (peat land), flood, storm, etc.)

\section{REFERENCES}

Astuti, Tri Maharaeni Puji. 2012. Ekofeminisme: Peran Perempuan dalam Lingkungan. Indonesian Journal of Conservation. Vol. 1 No. 1. 49-60.

Fadlurrahman, Lalu. 2014. Kinerja Implementasi Kebijakan Penanganan Perempuan Korban Kekerasan. Jurnal Kebijakan \& Administrasi Publik JKAP Vol. 18 No. 2. 161-184.

Kalu, Okhorafor, H., et., al. 2014. Rural Infrastructure Development: A Tool for Resolving Urbanization Crisis. A Case Study of South-Eastern Nigeria. World Environment (Journal). Vol. 4, No. 1.
14-21.

Mies, Maria \& Shiva, Vandhana. (2014). Ecofeminism (Critique. Influence. Change). London, UK: Zed Books.

Nugroho, Iwan, et., al., 2016. Promoting the Rural Development through the Ecotourism Activities in Indonesia. American Journal of Tourism Management, Vol. 5, No. 1. 9-18.

Nurpita, Anisa dan Aulia A. N. 2016. The Analysis of Development Disparities Inter Districts/City in Special Region of Yogyakarta (DIY) Province 20032013. JKAP (Jurnal Kebijakan dan Administrasi Publik). Vol. 20 No. 1. 23-37.

Prasetyanti, Retnayu, et., al. 2014. Developing Community Based Solid Waste Management Scenario in Surabaya, East Java, Indonesia: An Analysis Using System Dynamic Method. International Journal of Applied Sociology. Scientific and Academic Publishing. 19.

Prasetyanti, Retnayu. 2015. Slum Kampong Tourism "Jakarta Hidden Tour": Designing Eco-Cultural Based Pro-Poor Tourism. European Journal of Interdisciplinary Studies. 111-122.

Rijal, M. and Syaifullah Noer. 2013. Peran Modal Sosial dalam Pelestarian Hutan. Jurnal Kebijakan \& Administrasi Publik (JKAP). 20-36.

Setyati, Rina dan Warsito Utomo. 2015. Implementasi Kebijakan Penataan Ruang Terbuka Hijau Kawasan Perumahan Kota Banjarbaru. Jurnal Kebijakan \& Administrasi Publik JKAP. Vol. 19 No. 1. 59-70.

Shiva, Vandhana. (2015). Earth Democracy: Justice, Sustainability, and Peace. Berkeley, CA: North Atlantic Books.

Widayani, Retno dan Nisa A. R. 2013. Studi Tentang Kemunculan Modal Sosial. Jurnal Kebijakan \& Administrasi Publik (JKAP) Vol 17 No 2. 65-75 